\title{
Low Chronic Self-Esteem and Low Situational Self-Esteem: a literature review
}

\author{
Baixa Autoestima Crônica e Baixa Autoestima Situacional: uma revisão de literatura \\ Baja Autoestima Crónica y Baja Autoestima Situacional: una revisión de la literatura
}

'Universidade Federal do Ceará. Fortaleza, Ceará, Brazil.

"Universidade Estadual do Ceará. Fortaleza, Ceará, Brazil.

How to cite this article:

Natália Barreto de Castro'

ORCID: 0000-0001-7947-6332

Marcos Venícios de Oliveira Lopes'

ORCID: 0000-0001-5867-8023

Ana Ruth Macedo Monteiro"

ORCID: 0000-0002-1130-1293

Castro NB, Lopes MVO, Monteiro ARM. Low Chronic Self-Esteem and Low Situational Self-Esteem: a literature review. Rev Bras Enferm. 2020;73(1):e20180004. doi: http://dx.doi.org/10.1590/0034-7167-2018-0004

\section{Corresponding Author:}

Natália Barreto de Castro

E-mail: nataliabarretodecastro@hotmail.com

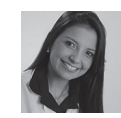

EDITOR IN CHIEF: Dulce Aparecida Barbosa ASSOCIATE EDITOR: Marcos Brandão

Submission: $01-25-2018$

Approval: 07-17-2018

\begin{abstract}
Objective: to develop a literature review about low self-esteem and components of the nursing diagnoses Low Chronic Self-Esteem and Low Situational Self-Esteem in patients with depressed mood. Method: an integrative literature review carried out in the Pubmed portal and in the Scopus and Web of Science electronic bibliographic databases. Depression and self-esteem descriptors were used, resulting in 32 articles. Results: literature indicated 7 clinical indicators and 14 etiological factors for low self-esteem. Conclusion: The clinical indicators Suicidal ideation and Ineffective treatment were more prevalent in the study. The etiological factors Stressful events and Stigmatization were the most frequent, both of which were suggested as new related factors for low self-esteem. Nursing diagnosis recognition can contribute to intervention strategy elaboration by the nurse, according to the urgent diagnostic and the individual's particularities.
\end{abstract}

Descriptors: Nursing Diagnosis; Self-Concept; Affect; Health Promotion; Mental Health.

\section{RESUMO}

Objetivo: desenvolver uma revisão de literatura acerca da baixa autoestima e dos componentes dos diagnósticos de enfermagem "Baixa Autoestima Crônica" e "Baixa Autoestima Situacional" em pacientes com humor deprimido. Método: revisão integrativa de literatura realizada no portal Pubmed e nas bases bibliográficas eletrônicas Scopus e Web of Science. Utilizaramse os descritores depression e self-esteem, resultando em 32 artigos. Resultados: a literatura apontou 7 indicadores clínicos e 14 fatores etiológicos para baixa autoestima. Conclusão: os indicadores clínicos "Ideação suicida" e "Enfretamento ineficaz" apresentaram maior predominância no estudo. Os fatores etiológicos "Eventos estressantes" e "Estigmatização" foram os mais frequentes, sendo ambos sugeridos como novos fatores relacionados para baixa autoestima. $\mathrm{O}$ reconhecimento do diagnóstico de enfermagem pode contribuir para elaboração de estratégias de intervenções pelo enfermeiro, conforme a urgência diagnóstica e as particularidades do indivíduo.

Descritores: Diagnóstico de Enfermagem; Autoestima; Humor; Promoção da Saúde; Saúde Mental.

\section{RESUMEN}

Objetivo: desarrollar una revisión de la literatura sobre la baja autoestima y los componentes de los diagnósticos de enfermería Baja Autoestima Crónica y Baja Autoestima Situacional en pacientes con estado de ánimo deprimido. Método: una revisión integradora de la literatura realizada en el portal Pubmed y en las bases de datos bibliográficas electrónicas Scopus y Web of Science. Se utilizaron los descriptores depression y self-esteem, resultando en 32 artículos. Resultados: Los indicadores clínicos Ideación suicida y Afrontamiento ineficaz fueron más frecuentes en el estudio. Conclusión: los indicadores clínicos Ideación suicida y Afrontamiento ineficaz fueron más frecuentes en el estudio. Los factores etiológicos Eventos estresantes y Estigmatización fueron los más frecuentes, los cuales fueron sugeridos como nuevos factores relacionados para la baja autoestima. El reconocimiento del diagnóstico de enfermería puede contribuir a la elaboración de estrategias de intervención por parte de la enfermera, según la urgencia diagnóstica y las particularidades del individuo.

Descriptores: Diagnóstico Enfermería; Promocion de la Salud; Autoimagen; Afecto; Salud Mental. 


\section{INTRODUCTON}

Nursing language standardization comprises a set of terms that can be used in care practice. The use of this vocabulary favors clinical judgments involved nursing diagnoses identification through nursing team care documentation ${ }^{(1)}$

In mental and psychiatric health care, nursing diagnosis is essential for nursing interventions selection and provision, from needs identification of each individual in the face of an existing or potential mental disorder(2). Specifically, patients with depression may present changes in the organization and interpretation of their sensory impressions, in order to give meaning to the environment ${ }^{(3-4)}$. This affective modulation may favor changes in the subject's self-concept, predisposing constant variations in his level of self-esteem. Therefore, it is expected that the symptoms presented by patients with depressed mood mainly lead to manifestations of nursing diagnoses belonging to domain 6, classified according to NANDA International (NANDA-I) taxonomy as Self-perception.

The Self-perception domain is defined as "Perception of self", being subdivided into three classes: Self-concept, Self-esteem and Body Image. It comprises 11 nursing diagnoses, being Low Chronic Self-esteem (LCS) and Low Situational Self-esteem (LSS) diagnoses with the focus on the problem, belonging to the class Self-esteem ${ }^{(1)}$.

BAC was developed in 1988, undergoing three reviews in 1996, 2008 and 2017. Currently, it is conceptualized as a"negative assessment and/or negative feelings about one's own abilities, lasting at least three months."The diagnosis comprises 14 defining characteristics (clinical indicators): Excessively seeks to self-reaffirm, Undecided behavior, Non-assertive behavior, Unsatisfactory visual contact, Guilt, Overly conformed, Dependent on the opinions of others, Exaggerates on negative feedback on self, Frequent lack of success in life events, Hesitates on trying new experiences, Passivity, Rejects positive feedback, Underestimates ability to deal with the situation and Shame ${ }^{(5)}$.

BAS was also developed in 1988, undergoing three reviews in 1996, 2000 and 2017. Currently, diagnosis is defined as "Development of negative perception about self-value in response to a current situation". It comprises 7 clinical indicators: Helplessness, Undecided behavior, Non-assertive behavior, Lack of purpose, Verbalizações autonegativas, Self-value situational challenge, Subestima a capacidade de lidar com a situação(5).

BAC includes 12 related (etiological) factors: Ineffective loss coping, Exposure to traumatic situations, Repeated failures, Cultural inconsistency, Spiritual inconsistency, Inadequate participation in groups, Inadequate belonging, Receives adequate affection, Receives insufficient approval from others, Repeated negative reinforcement, Improper respect of others and Psychiatric disorder. BAS comprises 15 etiological factors: Disturbed body image, Inconsistent behavior in relation to values, Decreased control over the environment, Helplessness pattern, Unrealistic self-expectations, Developmental transition, History of abandonment, History of abuse, History of loss, History of neglect, History of rejection, Failure pattern, functional impairment, and Physical illness ${ }^{(5)}$.

Studies on BAS and BAC nursing diagnoses are scarce in the literature, especially those applied to the psychiatric population. Although the diagnoses here have recently been reviewed for their structure in the NANDA-I taxonomy $(2018-2020)^{(5)}$, it is fundamental that new bibliographic studies can rectify the data that explain the diagnoses dynamics. In addition, BAC and BAS presented a minimum level of evidence, suggesting withdrawal of the BAS diagnosis in the latest NANDA-I's version (2018-2020) ${ }^{(5)}$

Recognition of predisposing factors and establishment of good clinical indicators in the diagnostic manifestation allow the prior identification of the health problem and a better understanding of its cause and effect. Furthermore, understanding the diagnostic manifestation makes possible the development of a more precise nursing care plan. Therefore, reducing factors that are difficult to diagnose is essential for their use as indicators of health in the assisted clientele ${ }^{(6)}$.

The idea guiding this literature review is the search for theoretical evidence that allow to understand and characterize the etiological factors that contribute to low self-esteem appearance in patients with depressed mood, as well as to verify which clinical indicators are present during nursing diagnoses manifestation under study.

\section{OBJECTIVE}

To develop a literature review about low self-esteem and components of the nursing diagnoses Low Chronic Self-Esteem and Low Situational Self-Esteem in patients with depressed mood.

\section{METHOD}

This is an integrative review, with the purpose of analyzing scientific evidence available in the literature on Low self-esteem. The following steps were delimited: elaboration of a guiding question; search and sampling in the literature; data collect; critical analysis of included studies; discussion of the integrative review results and presentation ${ }^{(7)}$.

At the review beginning, the following questions were elaborated: how is the term self-esteem addressed in the context of depression? What are the clinical indicators BAC and BAS? What are the factors that can lead to low self-esteem?

Search of articles was conducted in the Scopus and Web of Science databases and in the National Library of Medicine and National Institutes of Health (PubMed) portal. The articles were surveyed in April and May 2016, using as keywords the terms depression and self-esteem. At descriptor intersection, the Boolean operator AND was used. The selected descriptors were comprehensive in order to identify varied possibilities of association between self-esteem levels and possible depressed mood.

The initial sample was 808 articles, 307 identified in the Scopus database, 273 in the Web of Science and 228 in the PubMed portal. The following inclusion criteria were then applied to refine the search: complete articles and freely available in Portuguese, English or Spanish; published from 2011 to 2016; that addressed the subject under study; and responded to the guiding questions. The exclusion criteria were editorials, manuals and duplicate publications.

Each article was submitted to title and abstract reading to verify the presence of elements that could help in understanding the definition of self-esteem, and characteristics associated to a change in self-esteem. Subsequently, the selected articles were completely read. Hence, there was a final sample of 26 articles, 22 in the Scopus database, 2 in the Web of Science database and 2 in the PubMed portal. 
In order to update the data found in this literature review, a new article search was performed in the same databases and in the PubMed portal in June 2018. The terms depression and self-esteem were again used as keywords, and the Boolean operator AND.

In this new search, the initial sample counted 110 articles, 54 identified in the Scopus database, 32 in the Web of Science and 24 in the PubMed portal. The same inclusion and exclusion criteria were used for the first search, except for the publication period, which included the years 2016 and 2017. After title and abstract reading, 19 studies were selected to aid in the questioning of guiding questions. Subsequently, the selected articles were completely read. Thus, a sample of 6 articles was obtained at the end, 2 in the Scopus database, 1 in the Web of Science and 3 in the PubMed portal.

Therefore, articles search for this literature review construction, which took place in two moments, established a final sample of 32 articles, 24 in the Scopus database, 3 in the Web of Science and 5 in the PubMed portal. This selection process was represented in Figure 1.

\begin{tabular}{|c|}
\hline SCOPUS \\
\hline $\begin{array}{c}\text {-Initial sample: } 361 \\
\text { - Articles selected after title and abstract reading: } 83 \\
\text { • Final sample after full text reading: } 24\end{array}$ \\
\hline PUBMED \\
\hline $\begin{array}{c}\text { • Initial sample: } 252 \\
\text { - Articles selected after title and abstract reading: } 10 \\
\text { - Final sample after full text reading: } 5\end{array}$ \\
\hline
\end{tabular}

\begin{tabular}{|c|}
\hline WEB OF SCIENCE \\
\hline - Initial sample: 305 \\
\hline $\begin{array}{c}\text { Articles selected after title and abstract reading: } 12 \\
\cdot \text { Final sample after full text reading: } 3\end{array}$ \\
\hline
\end{tabular}

Figure 1 - Selection process of literature review studies, 2018

\section{RESULTS}

During article reading, the information that answered the guiding questions was extracted. The results found in the literature indicated 7 clinical indicators related to low self-esteem (Chart 1).

Among the 7 clinical indicators found after the literature search, the indicator "suicide deer" was more prevalent, with citation in five studies. "Ineffective coping" also showed a significant predominance in the literature review, being cited in 4 selected articles. "Rumination" and "Hopelessness" were cited in two studies. However, it is emphasized that the Hopelessness indicator was reinforced in the literature review, considering that it is a defining characteristic belonging to the BAS nursing diagnosis. Finally, "Insomnia" and "Virtual self-assertion search" were evidenced only in one study.

During the literature review, 14 antecedents related to low self-esteem were found, based on the information extracted from the guiding questions of the present study (Chart 2).

Among the 14 etiological factors found in the literary search, "Receives adequate affection" and "Disturbed body image" were already listed in the NANDA-I classification (2015-2017) ${ }^{(1)}$ for the diagnoses in studies. "Stressful events" and "Stigmatization" were the most frequent causal elements, with citations in 4 and 3 studies respectively, both being suggested as new related factors for low self-esteem.

Chart 1 - Synthesis of the results, referring to the clinical indicators "Low self-esteem", found after literature review, 2018

\begin{tabular}{|c|c|}
\hline $\begin{array}{l}\text { Clinical } \\
\text { indicators }\end{array}$ & References \\
\hline $\begin{array}{l}\text { 1. Suicidal } \\
\text { ideation }\end{array}$ & $\begin{array}{l}\text { Implicit and explicit self-esteem as concurrent } \\
\text { predictors of suicidal ideation, depressive } \\
\text { symptoms, and loneliness (CREEMERS et al., 2011)(8). } \\
\text { Effects of contingent self-esteem on depressive } \\
\text { symptoms and suicidal behavior (LAKEY et al., } \\
2014)^{(9)} \text {. } \\
\text { The association between suicide risk and self- } \\
\text { esteem in Japanese university students with } \\
\text { major depressive episodes of major depressive } \\
\text { disorder (MITSUI et al., 2014) } \\
\text { The relationships among gratitude, self-esteem, } \\
\text { depression, and suicidal ideation among } \\
\text { undergraduate students (LIN, 2015a) }{ }^{(11)} \text {. } \\
\text { Predictors of suicidal ideation in a community } \\
\text { sample: Roles of anger, self-esteem, and } \\
\text { depression (JANG et al., 2016) }\end{array}$ \\
\hline 2. Loneliness & $\begin{array}{l}\text { Implicit and explicit self-esteem as concurrent } \\
\text { predictors of suicidal ideation, depressive } \\
\text { symptoms, and loneliness (CREEMERS et al., 2011) })^{(8)} \text {. }\end{array}$ \\
\hline $\begin{array}{l}\text { 3. Ineffective } \\
\text { coping }\end{array}$ & $\begin{array}{l}\text { Self-esteem, psychological distress, and coping } \\
\text { styles in pregnant smokers and non-smokers } \\
\text { (VARESCON et al, 2013)(13). }^{(13)} \text { Relationships between cognitive coping, self- } \\
\text { esteem, anxiety and depression: A cluster-analysis } \\
\text { approach (DORON et al., 2013)(14). } \\
\text { The functional role of resignation orientation on } \\
\text { goal engagement, self-esteem, life satisfaction, and } \\
\text { depression (ASANO; ISHIMURA; KODAMA, 2014) }{ }^{(15)} \text {. } \\
\text { A closer look at self-esteem, perceived social } \\
\text { support, and coping strategy: a prospective study } \\
\text { of depressive symptomatology across the tran (LEE } \\
\text { et al., 2014) }\end{array}$ \\
\hline 4. Rumination & $\begin{array}{l}\text { Rumination mediates the prospective effect } \\
\text { of low self-esteem on depression: a five-wave } \\
\text { longitudinal study (KUSTER; ORTH; MEIER, 2012) } \\
\text { En Route to Depression: Self-Esteem Discrepancies } \\
\text { and Habitual Rumination (PHILLIPS; HINE, 2016) }{ }^{(18)} \text {. }\end{array}$ \\
\hline 5. Hopelessness & $\begin{array}{l}\text { Self-esteem Instability and Psychological } \\
\text { Adjustment (ZEIGLER-HILL; WALLACE, 2012) } \\
\text { The Effect of Automatic Thoughts on } \\
\text { Hopelessness: Role of Self-esteem as a Mediator } \\
(\text { ÇAKAR, 2014)(20). }\end{array}$ \\
\hline 6. Insomnia & $\begin{array}{l}\text { Optimism and self-esteem are related to sleep. } \\
\text { Results from a large community-based sample } \\
\text { (LEMOLA et al., 2013) } \\
\text { (21). }\end{array}$ \\
\hline $\begin{array}{l}\text { 7. Virtual self- } \\
\text { assertion search }\end{array}$ & $\begin{array}{l}\text { Relationship of Internet addiction with self- } \\
\text { esteem and depression in university students } \\
\text { (BAHRAINIAN et al., 2014)(22). } \\
\text { Internet Addiction and Relationships with } \\
\text { Insomnia, Anxiety, Depression, Stress and Self- } \\
\text { Esteem in University Students: A Cross-Sectional } \\
\text { Designed Study (YOUNES et al., 2016) } \\
\text { Problematic Social Media Use: Results from } \\
\text { a Large-Scale Nationally Representative } \\
\text { Adolescent Sample (BA'NYAl et al., 2017)(24). }\end{array}$ \\
\hline
\end{tabular}


Chart 2 - Results synthesis regarding the "Low self-esteem" etiological factors found after literature review, 2018

\begin{tabular}{|c|c|}
\hline Etiological factors & References \\
\hline $\begin{array}{l}\text { 1. Receives } \\
\text { adequate affection }\end{array}$ & $\begin{array}{l}\text { The relationships among gratitude, self-esteem, depression, and suicidal ideation among undergraduate students (LIN, } \\
2015 a)^{(11)} \text {. } \\
\text { Gratitude and depression in young adults: The mediating role of self-esteem and well-being (LIN, 2015b) })^{(25)} \text {. }\end{array}$ \\
\hline $\begin{array}{l}\text { 2. Reduction or } \\
\text { absence of social } \\
\text { support }\end{array}$ & $\begin{array}{l}\text { A closer look at self-esteem, perceived social support, and coping strategy: a prospective study of depressive } \\
\text { symptomatology across the tran (LEE et al., 2014)(16). } \\
\text { Hope, social support, and depression among Hong Kong youth: personal and relational self-esteem as mediators (DU; } \\
\text { KING; CHU, 2016) }\end{array}$ \\
\hline $\begin{array}{l}\text { 3. Disturbed body } \\
\text { image }\end{array}$ & $\begin{array}{l}\text { The mediating effect of self-esteem, depression and anxiety between satisfaction with body appearance and problematic } \\
\text { internet use (KORONCZAl et al., 2013) }{ }^{(27)} \text {. }\end{array}$ \\
\hline $\begin{array}{l}\text { 4. Negative } \\
\text { resignation }\end{array}$ & $\begin{array}{l}\text { The functional role of resignation orientation on goal engagement, self-esteem, life satisfaction, and depression (ASANO; } \\
\text { ISHIMURA; KODAMA, 2014) }{ }^{(15)} \text {. }\end{array}$ \\
\hline $\begin{array}{l}\text { 5. Low mindful } \\
\text { acceptance }\end{array}$ & $\begin{array}{l}\text { Buffering low self-esteem: The effect of mindful acceptance on the relationship between self-esteem and depression } \\
\text { (MICHALAK et al., 2011) }\end{array}$ \\
\hline $\begin{array}{l}\text { 6. Maladaptive } \\
\text { perfectionism }\end{array}$ & $\begin{array}{l}\text { Using SEM to Examine the Dimensions of Perfectionism and Investigate the Mediating Role of Self-Esteem between } \\
\text { Perfectionism and Depression in China (ZHANG; CAI, 2012)(29). }\end{array}$ \\
\hline 7. Stigmatization & $\begin{array}{l}\text { Protecting self-esteem from stigma: a test of different strategies for coping with the stigma of mental illness (ILIC et al., } \\
2011)^{(30)} \text {. } \\
\text { Association of social anxiety with stigmatisation and low self-esteem in remitted bipolar patients (AYDEMIR; AKKAYA, 2013) } \\
\text { (31). } \\
\text { Brief Version of the Internalized Stigma of Mental IIIness (ISMI) Scale: Psychometric Properties and Relationship to } \\
\text { Depression, Self Esteem, Recovery Orientation, Empowerment, and Perceived Devaluation and Discrimination (BOYD; } \\
\text { DeFORGE; OTILINGAM, 2014) } \\
\text { Stigma resistance and its association with internalised stigma and psychosocial outcomes among psychiatric outpatients } \\
(\text { LAU, et al., 2017)(33). }\end{array}$ \\
\hline $\begin{array}{l}\text { 8. Unsatisfactory } \\
\text { family cohesion }\end{array}$ & $\begin{array}{l}\text { A path analysis: a model of depression in Korean women with breast cancer-mediating effects of self-esteem and hope } \\
\text { (TAE; HEITKEMPER; KIM, 2012)(34). } \\
\text { Coparenting after marital dissolution and children's mental health: a systematic review (LAMELA; FIGUEIREDO, 2016) }{ }^{(35)} \text {. }\end{array}$ \\
\hline 9. Fatigue & $\begin{array}{l}\text { A path analysis: a model of depression in Korean women with breast cancer-mediating effects of self-esteem and hope } \\
(\text { TAE; HEITKEMPER; KIM, 2012) } \\
\text { (34). }\end{array}$ \\
\hline $\begin{array}{l}\text { 10. Inadequate } \\
\text { perception of health } \\
\text { status }\end{array}$ & 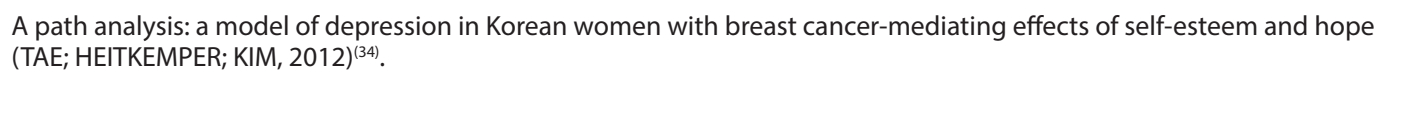 \\
\hline $\begin{array}{l}\text { 11. Impaired } \\
\text { religiosity }\end{array}$ & $\begin{array}{l}\text { A path analysis: a model of depression in Korean women with breast cancer-mediating effects of self-esteem and hope } \\
\text { (TAE; HEITKEMPER; KIM, 2012) }^{(34)} \text {. }\end{array}$ \\
\hline $\begin{array}{l}\text { 12. Low financial } \\
\text { income }\end{array}$ & $\begin{array}{l}\text { A path analysis: a model of depression in Korean women with breast cancer-mediating effects of self-esteem and hope } \\
\left(\text { (TAE; HEITKEMPER; KIM, 2012) }^{(34)} \text {. }\right.\end{array}$ \\
\hline 13. Stressful events & $\begin{array}{l}\text { Social support and self-esteem as mediators between stress and antepartum depressive symptoms in rural pregnant } \\
\text { women (JESSE, KIM; HERNDON, 2014) } \\
\text { Self-Esteem, Narcissism, and Stressful Life Events: Testing for Selection and Socialization (ORTH; LUCIANO, 2015) })^{(37)} \text {. } \\
\text { Moderated Mediation Effect of Self-esteem on the Relationship Between Parenting Stress and Depression According to } \\
\text { Employment Status in Married Women: A Longitudinal Study Utilizing Data from Panel Study on Korean Children (HAN; } \\
\text { KIM, 2017) }{ }^{(38)} \text {. }\end{array}$ \\
\hline $\begin{array}{l}\text { 14. Depressed } \\
\text { mood }\end{array}$ & $\begin{array}{l}\text { Relationship between attributional style, perceived control, self-esteem, and depressive mood in a nonclinical sample: A } \\
\text { structural equation-modelling approach (LEDRICH; GANA, 2013)(39). }\end{array}$ \\
\hline
\end{tabular}

\section{DISCUSSION}

Suicidal ideation is a thought or act of subtracting one's own life. It is usually associated with depressive disorders, and does not have an exclusive age group. It is not a static phenomenon, so the decision to engage in suicidal behavior may arise impulsively without further consideration of the idea, but it may also be the apex of prolonged rumination ${ }^{(40)}$.

Regarding the predominant clinical indicator, it was observed that in individuals with fragile low self-esteem described as highly contingent, depressive symptoms and suicidal behaviors manifest themselves more intensely. The contingency of self-esteem is related to its instability, by failing to comply with norms ${ }^{(9)}$. According to Mitsui ${ }^{(10)}$ and Jang ${ }^{(12)}$, low self-esteem was also evaluated with a factor susceptible to suicidal ideation.

Self-esteem can be classified as explicit and implicit. Self-mindful feeling of self-worth and acceptance of an individual categorizes explicit self-esteem. Implicit self-esteem may be related to the internalization of psychological problems, being defined as a relatively automatic and non-self-mindful evaluation that guides 
spontaneous reactions and self-relevant encouragement ${ }^{(8)}$. In this study, explicit self-esteem lower levels were associated with higher levels of suicidal ideation and loneliness. Implicit and explicit self-esteem interaction was also associated with suicidal ideation, indicating that participants with high implicit self-esteem, combined with low self-esteem level, had a higher suicidal ideation.

In relation to loneliness, which has an important intrapersonal element, because it reflects a disparity between real social relations and the desired social relations; implicit self-esteem may be indicative of desired social relations, while explicit self-esteem may represent real social relations ${ }^{(8)}$. According to NANDA-I (2015$2017)^{(1)}$, this indicator is presented with a risk nursing diagnosis, which is defined as "vulnerability to experiencing discomfort associated with the desire or need for more contact with others, which can compromise health".

Individuals with low self-esteem generally have less confidence in the initial approach to problems and therefore seek more information before offering solutions and decision-making. Inability to adapt to life stress can favor changes in coping strategies, increasing susceptibility to negative psychological outcomes. Therefore, ineffective coping high levels represent a particular risk factor for depressive symptomatology, decreasing the high self-esteem advantage $\mathrm{e}^{(13-14,16,41)}$.

"Ineffective coping" also showed a significant predominance in the literature review, being cited in 4 articles selected. According to NANDA-I (2015-2017) (1), "Ineffective coping" is considered a problem-focused nursing diagnosis, defined as "inability to perform a valid assessment of stressors, inadequate choices of responses and/or inability to utilize available resources".

Another possible clinical indicator for low self-esteem found during the literary search was rumination. This is conceptualized as a persevering thought about feelings and problems. Individuals with low self-esteem are likely to experience more negative effects when thinking about themselves and, consequently, may be motivated to suppress self-related thoughts, which have the ironic effect of increasing ruminal tendencies. In addition, individuals with low self-esteem tend to hide their bad qualities subjectively perceived by others ${ }^{(17)}$.

As expected, habitual rumination levels increase as the size of the absolute discrepancy between explicit and implicit self-esteem increases. Contrary to the hypothesis, fragile self-esteem (low implicit and explicit high) and impaired self-esteem (high implicit and explicit low) were differentially associated with rumination. Discrepancies in absolute self-esteem were significantly associated with rumination for participants with impaired self-esteem but were not significantly related to rumination for individuals with fragile self-esteem ${ }^{(18)}$.

Zeigler-Hill and Wallace ${ }^{(19)}$ and Çakar ${ }^{(20)}$ state that low self-esteem predicts hopelessness at a significant level. This indicator seems to increase when the individual manifests cognitive distortions, such as a negative sense of self, accusing himself, despairing and seeing life in a dangerous way. It was determined that people who perceive themselves more negatively present hopelessness higher levels and self-esteem lower levels. "Hopelessness" is contemplating in the BAS nursing diagnosis, according to the NANDA-I classification (2015-2017)(1).
Insomnia has also been pointed out in studies as an expected consequence of low self-esteem. The importance of nocturnal sleep for physical and mental health is widely recognized and has been widely studied. Sleep hours of less than 7 hours as well as greater than 8 hours are associated with a variety of physical and psychological problems such as increased risk of coronary heart disease, hypertension and anxiety and depression disorders. Insomnia obtained lower scores on self-esteem, indicating that short sleep has a relation with lower self-esteem when compared to individuals with prolonged sleep ${ }^{(21)}$.

Finally, the literature showed that the use of the Internet is closely associated with self-perception of the individual, functioning as a style of coping and a way to compensate for some behaviors, such as low self-esteem ${ }^{(23-24)}$. It is believed that Internet users with diminished self-esteem obtain great satisfaction by using the medium of communication, by allowing them to assume different personalities and social identities ${ }^{(22)}$.

According to Koronczai ${ }^{(28)}$, individuals immersed in virtual reality media can disguise and/or conceal their real physical characteristics, making it possible to assume a desired alternative virtual appearance. Thus, it is noted that the search for self-assertion in the virtual environment can characterize the consequence of self-esteem low levels.

Regarding etiological factors, inadequate affection reception is a related factor adopted by NANDA-I (2015-2017)(1), belonging to $B A C$. One of the forms of inadequate affection is represented by the insufficiency/absence of grateful behavior, which is defined as gratitude or appreciation, considered essential for the individual's moral and social behavior. Therefore, inadequate affection is able to develop a model of negative representation of self as unworthy and unworthy of affection, contributing to an inappropriate self-assessment ${ }^{(11,25)}$.

Reduction or absence of social support seems to contribute to distorted perception development, negative ideas about self, others and relationships, as well as promoting greater sensitivity to social rejection and reproach. Self-esteem is likely to be predicted negatively through insufficient awareness of social support, and this is due to a feedback process ${ }^{(16,26)}$. NANDA-I $(2015-2017)^{(1)}$ states that BAC exposes related factors that represent a fragment of the deficiency between the interaction of social support and low self-esteem, being titled as "Inadequate participation in groups", "Inadequate belonging" and "Receives insufficient approval from others". For BAS, the reduction or absence of social support seems to correspond more comprehensively to "Inadequate recognition".

According to Koronczai's ${ }^{(27)}$ study, dissatisfaction with body appearance favors the exclusion of personal contacts, which can generate social phobia. Disturbed body image represent important antecedents for the presence of low self-esteem. According to NANDA-I (2015-2017) $)^{(1)}$, “Disturbed body image" is present in BAS.

Renunciation or withdrawal, considered as an act of abdication of something that someone aims, is also discussed as a coping strategy, being as important as achieving goals. Negative resignation has a positive effect on cognitive avoidance, achievement desire disappearance, and new goal definition. On the other hand, individuals with negative resignation are pessimistic and easily give up on their goals, generating self-performance and self-esteem low levels dissatisfaction ${ }^{(15)}$. 
Michalak's ${ }^{(28)}$ study describes mindful acceptance or mindfulness as an ability of the individual to intentionally focus attention on the experience of the present moment in an open and nonjudgmental attitude. Authors state that low mindful acceptance prevents individuals from recognizing that thoughts and feelings are mind events, favoring the development of negative emotions as a consequence of cognitions related to low self-esteem. This, in turn, allows vicious cycles establishment caused by dysfunctional experience and self-perpetuation of ruminal thoughts avoidance. Therefore, in low-mindful acceptance, the individual cannot focus his attention on the current experience, making a judgment and assessment in a wrong way of situations, encouraged evasion and restlessness behavior. Hence, it seems plausible that lowminded accessibility facilitates the tendency of low self-esteem and triggering of depressive states.

Dysfunctional, maladaptive or neurotic perfectionism consists of extreme self-criticism and a chronic sense of inadequacy in meeting expectations and performance standards. Therefore, excessive pursuit of perfection is a common response to an unfavorable view of self-esteem, that is, low self-esteem is inevitable for the perfectionist, for even milder negative feedback can be viewed as failure, categorizing imperfect performance and a meaningful indication of uselessness ${ }^{(29)}$.

The stigma of mental disorders is a major problem in psychiatric patients adaptation. For Aydemir and Akkaya ${ }^{(31)}$ who studied the association between bipolar disorder and social anxiety, it was possible to evidence a negative correlation between stigmatization and self-esteem. The internalized stigma of mental illness prevents patient from recovering, being linked to depression increase, decreased self-esteem, reduced orientation towards recovery, reduced capacity and perceived increase of devaluation and discrimination ${ }^{(30,33)}$

For Ledrich and Ghana ${ }^{(39)}$, individuals with depressed mood are less likely to perceive signs of belonging and inclusion in social interactions, being more likely to receive rejection attitudes and insufficient care responses. In addition, depressed individuals typically generate interpersonal stress, predisposing depressive symptoms. Thus, depressed mood seems to compromise important sources of self-esteem, which may result in self-esteem lower levels.

Self-esteem is often conceptualized as a psychological protection feature that allows people to adapt and recover from stressful events. Stress is defined as an imbalance between daily discontentment, emotional demands, and coping strategies ${ }^{(36)}$. People exposed to stress high levels may be more likely to perceive situations in a negative way, increasing the risk of acquiring depression. Research on personality development supports the principle of plasticity, which states that the characteristics of self-esteem can be influenced by environmental factors. Stressful events have the potential to cause individual variability in the development of self-esteem because they occur at different moments in life ${ }^{(37-38,42-43)}$. Thus, stressful events can provide detrimental changes in self-esteem.

Tae, Heitkemper, Kim's ${ }^{(34)}$ study, which aimed to verify the effects of breast cancer mediation on Korean women self-esteem, five antecedent factors for low self-esteem were identified: unsatisfactory family cohesion, fatigue, inadequate perception of health status, impaired religiosity, and low financial income.
According to the authors of the aforementioned study and Lamela and Figueiredo ${ }^{(35)}$, unsatisfactory family cohesion makes it impossible for the individual to verify the affection of their relatives, generating a distorted and negative idea of their self-concept. Fatigue symptom, often associated with the pain symptom, provides a feeling of extreme tiredness, making the individual unable to perform their daily activities. This condition predisposes self-esteem high levels with consequent signs of feelings of hopelessness and depressive symptomatology ${ }^{(34)}$.

Inadequate perception of health status refers to the understanding of current health status associated with clinical conditions that can generate feelings of shame and embarrassment. This sensation may interfere with self-concept and patient recovery and, therefore, lead to low self-esteem levels. It is also observed that impaired religiosity can affect self-esteem because, especially at critical moments during health restoration, the absence of spiritual support accentuates feelings of hopelessness closely correlated with low self-esteem levels. Finally, low financial income might limit access to health and leisure resources, causing a feeling of helplessness and mental overload in the individual, resulting in decreased self-esteem ${ }^{(34)}$.

\section{Study limitations}

A shortage of studies developed with BAC and BAS nursing diagnoses was observed in the literature. The few findings were limited to research on diagnostic profile, which briefly describes the manifestation of the phenomenon studied.

\section{Contributions to Nursing}

In clinical practice, the accurate characterization of a nursing diagnosis allows the nurse to execute a qualified care plan, capable of serving the individuality of each patient. Therefore, this will have a direct and positive impact on the recovery of the assisted clientele.

\section{CONCLUSION}

"Suicidal ideation" and "Ineffective coping" were more prevalent in the study. The presence of hopelessness, which represents a nursing diagnosis according to NANDA-I, was reinforced in the integrative review with a clinical indicator for low self-esteem.

Regarding etiological factors, Stressful events and Stigmatization were the most frequent, both being suggested as new related factors for low self-esteem. Receives adequate affection and Disturbed body image, already listed in the NANDA-I classification, were also identified as causal elements for the diagnoses in studies.

The integrative review allows to better understand the phenomenon dynamics under study, from a problem configuration. For this, it becomes necessary to know the components that predispose and/or designate the diagnostic manifestation. Therefore, nursing diagnosis presence represents an established health problem, which can be extinguished early from the recognition of its structural and behavioral evidence. Therefore, the prior confirmation of a nursing diagnosis will allow nurses to develop strategies for effective interventions, through diagnostic urgency and according to the particularities of each individual. 


\section{REFERENCES}

1. Herdman TH, Kamitsuru SE. Nanda International. Nursing Diagnoses 2015-17: Definitions and Classification. Oxford: Wiley Blackwell; 2014.

2. Stefanelli MC, Fukuda IMK, Arantes EC. Enfermagem psiquiátrica: em suas dimensões assistenciais. Barueri: Manole; 2008.

3. Louzã Neto MR, Elkis H. Psiquiatria Básica. 2a ed. Porto Alegre: Artmed; 2007.

4. Dalgalarrondo P. Psicopatologia e semiologia dos transtornos mentais. 2a ed. Porto Alegre: Artmed; 2008.

5. Herdman TH, Kamitsuru SE. Nanda International. Nursing Diagnoses 2018-2020: Definitions and Classification. Oxford: Wiley Blackwell; 2017.

6. Pereira JMV, Cavalcanti ACD, Lopes MVO, Silva VG, Souza RO, Gonçalves LC. Accuracy in inference of nursing diagnoses in heart failure patients. Rev Bras Enferm. 2015;68(3):603-9. doi: 10.1590/0034-7167.2015680417i

7. Souza MT, Silva MD, Carvalho R. Integrative review: what is it? How to do it?. Einstein. 2010;8(1):102-6. doi: 10.1590/s1679-45082010rw1134

8. Creemers DH, Scholte RH, Engels RC, Prinstein MJ, Wiers RW. Implicit and explicit self-esteem as concurrent predictors of suicidal ideation, depressive symptoms, and loneliness. J Behav Ther Exp Psychiatry. 2012;43(1):638-46. doi: 10.1016/j.jbtep.2011.09.006

9. Lakey CE, Hirsch JK, Nelson LA, Nsamenang SA. Effects of contingent self-esteem on depressive symptoms and suicidal behavior. Death Stud. 2014;38(6-10):563-70. doi: 10.1080/07481187.2013.809035

10. Mitsui N, Asakura S, Shimizu Y, Fujii Y, Toyomaki A, Kako Y, et al. The association between suicide risk and self-esteem in Japanese university students with major depressive episodes of major depressive disorder. Neuropsychiatr Dis Treat. 2014;10:811-6. doi: 10.2147/NDT.S59349.

11. Lin CC. The relationships among gratitude, self-esteem, depression, and suicidal ideation among undergraduate students. Scand J Psychol. 2015;56(6):700-7. doi: 10.1111/sjop.12252

12. Jang JM, Park Jl, Oh KY, Lee KH, Kim MS, Yoon MS, et al. Predictors of suicidal ideation in a community sample: Roles of anger, self-esteem, and depression. Psychiatry Res. 2014;216(1):74-81. doi: 10.1016/j.psychres.2013.12.054

13. Varescon I, Leignel S, Gérard C, Aubourg F, Detilleux M. Self-esteem, psychological distress, and coping styles in pregnant smokers and nonsmokers. Psychol Rep. 2013;113(3):935-47. doi: 10.2466/13.20.PR0.113x31z1

14. Doron J, Thomas-Ollivier V, Vachon H, Fortes-Bourbousson M. Relationships between cognitive coping, self-esteem, anxiety and depression: A cluster-analysis approach. Pers Individ Dif. 2013;55(5):515-20. doi: 10.1016/j.paid.2013.04.017

15. Asano K, Ishimura I, Kodama M. The functional role of resignation orientation on goal engagement, self-esteem, life satisfaction, and depression. Health Psychol Res. 2014;22;2(3):1882. doi: 10.4081/hpr.2014.1882

16. Lee C, Dickson DA, Conley CS, Holmbeck GN. A closer look at self-esteem, perceived social support, and coping strategy: a prospective study of depressive symptomatology across the transition to college. J Clin Psychol. 2014;33(6):560-85. doi: 10.1521/jscp.2014.33.6.560

17. Kuster F, Orth U, Meier LL. Rumination mediates the prospective effect of low self-esteem on depression: a five-wave longitudinal study. Pers Soc Psychol Bull. 2012;38(6):747-59. doi: 10.1177/0146167212437250

18. Phillips WJ, Hine DW. En route to depression: self-esteem discrepancies and habitual rumination. J Pers. 2016;84(1):79-90. doi: 10.1111/ jopy. 12141

19. Zeigler-Hill V, Wallace M. Self-esteem instability and psychological adjustment. Self Identity. 2012;11(3):317-42. doi: $10.1080 / 15298868.2011 .567763$

20. Çakar FS. The effect of automatic thoughts on hopelessness: role of self-esteem as a mediator. Educ Sci Theory Pract. 2014;14(5):10-6. doi: 10.12738/estp.2014.5.2132

21. Lemola S, Räikkönen K, Gomez V, Allemand M. Optimism and self-esteem are related to sleep. Results from a large community-based sample. Int J Behav Med. 2013;20(4):567-71. doi: 10.1007/s12529-012-9272-z

22. Bahrainian SA, Alizadeh $\mathrm{KH}$, Raeisoon MR, Gorji OH, Khazaee A. Relationship of Internet addiction with self-esteem and depression in university students. J Prev Med Hyg [Internet]. 2014 [cited 2017 Dec 22];55(3):86-9. Available from: https://www.ncbi.nlm.nih.gov/pmc/ articles/PMC4718307/

23. Younes F, Halawi G, Jabbour H, El Osta N, Karam L, Hajj A, et al. Internet addiction and relationships with insomnia, anxiety, depression, stress and self-esteem in university students: a cross-sectional designed study. PLoS One. 2016;11(9):e0161126. doi: 10.1371/journal. pone. 0161126

24. Bányai F, Zsila A, Király O, Maraz A, Elekes Z, Griffiths MD, et al. Problematic social media use: results from a large-scale nationally representative adolescent sample. PLoS ONE. 2017;12(1):e0169839. doi: 10.1371/journal.pone.0169839

25. Lin CC. Gratitude and depression in young adults: The mediating role of self-esteem and well-being. Pers Individ Dif. 2015;87:30-4. doi: 10.1016/j.paid.2015.07.017

26. Du H, King RB, Chu SK. Hope, social support, and depression among Hong Kong youth: personal and relational self-esteem as mediators. Psychol Health Med. 2016;21(8):926-31. doi: 10.1080/13548506.2015.1127397

27. Koronczai B, Kökönyei G, Urbán R, Kun B, Pápay O, Nagygyörgy K, et al. The mediating effect of self-esteem, depression and anxiety 
between satisfaction with body appearance and problematic internet use. Am J Drug Alcohol Abuse. 2013;39(4):259-65. doi: $10.3109 / 00952990.2013 .803111$

28. Michalak J, Teismann T, Heidenreich T, Ströhle G, Vocks S. Buffering low self-esteem: The effect of mindful acceptance on the relationship between self-esteem and depression. Pers Individ Dif. 2011;50(5):751-4. doi: 10.1016/j.paid.2010.11.029

29. Zhang B, Cai T. Using SEM to Examine the Dimensions of Perfectionism and Investigate the Mediating Role of Self-Esteem between Perfectionism and Depression in China. J Psychol Couns Sch. 2012;22:44-57. doi: 10.1017/jgc.2012.3

30. Ilic M, Reinecke J, Bohner G, Röttgers HO, Beblo T, Driessen M, et al. Protecting self-esteem from stigma: a test of different strategies for coping with the stigma of mental illness. Int J Soc Psychiatry. 2012;58(3):246-57. doi: 10.1177/0020764010392058

31. Aydemir O, Akkaya C. Association of social anxiety with stigmatisation and low self-esteem in remitted bipolar patients. Acta Neuropsychiatr. 2011;23(5):224-8. doi: 10.1111/j.1601-5215.2011.00565.x

32. Boyd JE, Otilingam PG, Deforge BR. Brief version of the Internalized Stigma of Mental IIIness (ISMI) scale: psychometric properties and relationship to depression, self esteem, recovery orientation, empowerment, and perceived devaluation and discrimination. Psychiatr Rehabil J. 2014;37(1):17-23. doi: 10.1037/prj0000035

33. Lau YW, Picco L, Pang S, Jeyagurunathan A, Satghare P, Chong AS et al. Stigma resistance and its association with internalised stigma and psychosocial outcomes among psychiatric outpatients. Psychiatry Res. 2017;257:72-8. doi: 10.1016/j.psychres.2017.07.027

34. Tae YS, Heitkemper M, Kim MY. A path analysis: a model of depression in Korean women with breast cancer-mediating effects of self-esteem and hope. Oncol Nurs Forum. 2012;39(1):E49-57. doi: 10.1188/12.ONF.E49-E57

35. Lamela D, Figueiredo B. Coparenting after marital dissolution and children's mental health: a systematic review. J Pediatr (Rio J). 2016;92(4):331-42. doi: 10.1016/j.jped.2015.09.011

36. Jesse DE, Kim H, Herndon C. Social support and self-esteem as mediators between stress and antepartum depressive symptoms in rural pregnant women. Res Nurs Health. 2014;37(3):241-52. doi: 10.1002/nur.21600

37. Orth U, Luciano EC. Self-esteem, narcissism, and stressful life events: testing for selection and socialization. J Pers Soc Psychol. 2015;109(4):707-21. doi: 10.1037/pspp0000049

38. Han JW, Kim JH. Moderated mediation effect of self-esteem on the relationship between parenting stress and depression according to employment status in married women: a longitudinal study utilizing data from panel study on Korean children. Asian Nurs Res (Korean Soc Nurs Sci). 2017;11(2):134-41. doi: 10.1016/j.anr.2017.05.007

39. Ledrich J, Gana K. Relationship between attributional style, perceived control, self-esteem, and depressive mood in a nonclinical sample: a structural equation-modelling approach. Psychol Psychother. 2013;86(4):413-30. doi: 10.1111/j.2044-8341.2012.02067.x

40. Sadock BJ, Sadock VA. Manual de Psiquiatria Clínica: referência rápida. 5a ed. Porto Alegre: Artmed; 2012.

41. Nasiri S, Kordi M, Gharavi MM. A comparative study of the effects of problem-solving skills training and relaxation on the score of selfesteem in women with postpartum depression. Iran J Nurs Midwifery Res [Internet]. 2015 [cited 2017 Dec 20];20(1):105-12. Available from: https://www.ncbi.nlm.nih.gov/pmc/articles/PMC4325401/

42. Lee JS, Joo EJ, Choi KS. Perceived stress and self-esteem mediate the effects of work-related stress on depression. Stress Health. 2013;29(1):75-81. doi: 10.1002/smi.2428

43. Lee-Flynn SC, Pomaki G, Delongis A, Biesanz JC, Puterman E. Daily cognitive appraisals, daily affect, and long-term depressive symptoms: the role of self-esteem and self-concept clarity in the stress process. Pers Soc Psychol Bull. 2011;37(2):255-68. doi: $10.1177 / 0146167210394204$ 